\title{
OLFACTORY BULB TRANSPLANTATION IN COMPLETE SPINAL CORD INJURY: AXONAL REGENERATION AND LOCOMOTOR RECOVERY
}

\author{
TRANSPLANTE DE BULBO OLFATÓRIO EM LESÃO MEDULAR COMPLETA: \\ REGENERAÇÃO AXONAL E RECUPERAÇÃO LOCOMOTORA
}

\author{
TRASPLANTE DE BULBO OLFATORIO EN LESIONES MEDULARES COMPLETAS: \\ REGENERACIÓN AXONAL Y RECUPERACIÓN LOCOMOTORA
}

Carlos Abraham Arellanes-Chávez ${ }^{1}{ }^{1,2}$, Ariana Martínez Bojórouez², Ernesto Ramos Martínez ${ }^{1}$

\begin{abstract}
Objectives: To determine whether the intervention in rats is effective in terms of spinal cord regeneration and locomotor recovery, in order to obtain sufficient evidence to apply the therapy in humans. Methods: a randomized, controlled, experimental, prospective, randomized trial was conducted, with a sample of 15 adult female Sprague-Dawley rats weighing 250 gr. They were divided into three equal groups, and trained for 2 weeks based on Pavlov's classical conditioning method, to strengthen the muscles of the 4 legs, stimulate the rats mentally, and keep them healthy for the surgery. Results: It was observed that implantation of these cells into the site of injury may be beneficial to the process of spinal cord regeneration after spinal trauma, to mediate secretion of neurotrophic and neuroprotective chemokines, and that the OECs have the ability to bridge the repair site and decrease the formation of gliosis, creating a favorable environment for axonal regeneration. Conclusion: It is emphasized that the olfactory ensheathing glial cells possess unique regenerative properties; however, it was not until recently that the activity of promoting central nervous system regeneration was recognized.
\end{abstract}

Keywords: Spinal cord injuries; Spinal cord regeneration; Olfactory bulb.

\section{RESUMO}

Objetivos: Verificar se intervenção em ratos tem eficácia comprovada na regeneração medular e na recuperação locomotora, visando obter evidência suficiente para aplicar a terapia ao ser humano. Métodos: Estudo prospectivo experimental controlado e randomizado, com amostra de 15 ratas Sprague-Dawley adultas pesando 250 gramas. Os indivíduos foram divididos em três grupos que foram treinados durante 2 semanas pelo método de Pavlov de condicionamento clássico, de modo a fortalecer os músculos das quatro patas, estimular os animais mentalmente e mantê-los saudáveis para a cirurgia. Resultados: Constatou-se que a implantação dessas células no local da lesão pode ser benéfica para o processo de regeneração medular depois do trauma, visto que medeia secreção de quimiocinas neurotróficas e neuroprotetoras; da mesma maneira que as células olfatórias da glia (OEC) têm a capacidade de fazer ponto no local do reparo e de diminuir a formação de gliose, criando ambiente propício para a regeneração axonal. Conclusão: Cabe destacar que as células olfatórias da glia têm propriedades regeneradoras únicas, porém, apenas recentemente sua atividade promotora de regeneração do sistema nervoso central foi reconhecida.

Descritores: Traumatismos da medula espinal; Regeneração da medula espinal; Bulbo olfatório.

\section{RESUMEN}

Objetivos: Si la intervención en ratas prueba su efectividad respecto a la regeneración medular y la recuperación locomotora con el fin de obtener evidencia suficiente para aplicar la terapia en humanos.Métodos: Se realizóun estudio prospectivo experimental controlado aleatorizado, donde se incluyóuna muestra de 15 ratas adultas hembras Sprague-Dawley de 250 gr. Se dividieron por tercias las cuales se entrenaron durante 2 semanas en base al método de Pavlov de condicionamiento clásico con el fin de fortalecer los músculos de las 4 patas, estimularlas anímicamente y mantenerlas saludables para el acto quirúrgico. Resultados: Se ha observado que el implante de estas células en el sitio de la lesión, puede resultar benéfico para el proceso de regeneración medular después del trauma al mediar la secreción de quimiocinas neurotróficas y neuroprotectoras, asímismo las OECs poseen la habilidad de puentear el sitio de reparación y disminuir la formación de gliosis creando un ambiente permisivo para la regeneración axonal. Conclusión: Cabe destacar que las células de la glia olfatoria poseen propiedades regeneradoras únicas, sin embargo no fue sino hasta hace poco que su actividad promotora de regeneración del sistema nervioso central se reconoció.

Descriptores: Traumatismos de la médula espinal; Regeneración de la medula espinal; Bulbo olfatorio.

\section{INTRODUCTION}

Spinal cord injuries (SCI) represent a complex disorder with multiple clinical symptoms, depending on the level and complexity of the injury. In general the rehabilitation and management of $\mathrm{SCl}$ is a relatively recent phenomenon. ${ }^{1}$
Cell transplantation therapies have received increasing attention in pre-clinical research, such as strategies for the treatment of spinal cord injuries. Olfactory ensheathing glia transplantation, which we reproduced in the laboratory, is a technique that has been widely studied, particularly by Ramón-Cueto, who demonstrated the ability

1. Hospital CIMA, Chihuahua, Chihuahua, Mexico.

2. Facultad de Medicina Universidad Autónoma de Chihuahua, Chihuahua, Mexico.

Study conducted at the Microsurgery Laboratory, Edificio de Investigación of the Facultad de Medicina of the Universidad Autónoma de Chihuahua, Chihuahua, Mexico. Correspondence: Haciendas del Valle \#7120-418, Plaza las Haciendas Chihuahua, Chihuahua. Mexico, C.P. 31238. drcarlosarellanes@gmail.com 
of the olfactory ensheathing glia to promote functional and histological repair in central nervous system (CNS) injuries. ${ }^{2}$

Based on observations that the olfactory system exhibits neurogenesis and sends axonal processes to the CNS for life, it was suggested that the OECs present unique regenerative properties. These cells enable axonal regeneration, direct the growing axons through the glial scar, have the ability to remove degenerated axons via phagocytosis, and produce channels through which recently-formed axons are guided for their regrowth, and while the OECs do not form myelin in the olfactory system, they do generate it once transplanted into the site of injury. ${ }^{3-5}$

Preclinical studies show that the effects of adult OECs are reproducible in experimental models of spinal cord lesions. ${ }^{6}$ In this study, we measured the effects of intraspinal transplantation of the olfactory bulb in a population of rats with acute spinal cord injury that can adequately simulate an acute $\mathrm{SCl}$ in a patient, in order to verify the usefulness of OEC transplantation in spinal cord regeneration after complete $\mathrm{SCl}$, and to measure functional recovery after transplantation and physical training..$^{7-9}$

Objective: To demonstrate the utility of olfactory bulb transplant in spinal cord regeneration after complete spinal cord injury. To measure functional recovery in rats with complete spinal cord section after olfactory bulb transplant. To demonstrate the axonal regeneration of complete spinal cord section after olfactory bulb transplant.

\section{METHODOLOGY}

A randomized controlled experimental prospective study was conducted, which included a sample of 15 syngeneic female adult Sprague-Dawley rats, weighing $250 \mathrm{~g}$. The rats were divided into thirds, which were trained for 2 weeks based on the Pavlov classical conditioning method, to strengthen the muscles of the 4 feet, stimulate the animals mentally, and keep them healthy for the surgical procedure. The training consisted in having the rats climb a mesh, which was tilted from 0 to 90 degrees every third day, according to the animal's response to the training. ${ }^{10}$ Once the two weeks of training were complete, the thirds were randomly divided into case rats, control rats and donor rats. All specimens were anesthetized with sodium thiopental in the peritoneal cavity.

The donor rats underwent craniectomy to remove both olfactory bulbs, which were immediately placed in a test tube with physiological saline solution. Immediately afterwards, a control rat was randomly selected, and a complete spinal cord section was performed at level T10, without implanting any olfactory bulb. The case rat was then submitted to microsurgery, to create a complete spinal cord injury at level T10, similar to that of the control rat in which one of the olfactory bulbs was implanted. The wound was then sutured in a single plane.

All the animals were given pre- and post-anesthetic care, except for the donor rats, which were sacrificed. One week postoperative, the training of both the case and control rats was resumed. The evolution of the experimental animals was video recorded.

Between the 80 and 120 days postoperative, depending on the clinical status of the rats, the spinal cord was removed. All the removed spinal cords were dyed with glial fibrillary acidic protein and submitted to histological immunohistochemical analysis.

It should be mentioned that the study met all the bioethical and regulatory criteria of animal protection.

\section{RESULTS}

In the immediate postsurgical period, all animals showed flaccid paralysis of both hind feet.

During the evolution, it was observed that the control rats died before 30 days of life, without showing any evidence of locomotor recovery; only 2 of the control rats managed to survive until 60 days.

Prior to its clinical deterioration and death, the spinal cord was removed for pathological study. It is worth mentioning that all the controls remained paraplegic until their deaths.

In the surgical act of removing the spinal cords, it was observed that the spinal cords of the control rats were completely sectioned, with the presence of abundant scar tissue in the skin, muscles, and subcutaneous tissue, which hampered the surgical approach. (Figure 1)

All the rats case evolved in a similar manner in terms of locomotor recovery: claw flexion of the feet at around day 12 postoperative, normal position on 4 feet by day 30, mobility of the thighs and ankles by day 60 , and return to walking on the hind feet at around day 90 postoperative, with weak and unstable gait, but at 140 days, the hind feet regained strength and the angle of mobility increased. (Table 1, Figure 2)

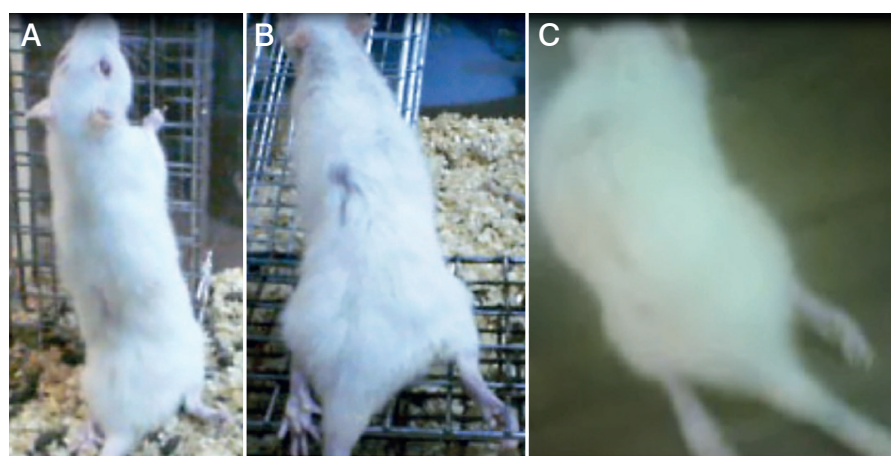

Figure 1. A) Control rat first week postoperative, complete paraplegia of the hind feet is observed. B) Control rat 30 days postoperative, complete paraplegia of the hind feet continues. C) 60 days postoperative, there are no signs of locomotor recovery.

Table 1. Evolution postoperative.

\begin{tabular}{|c|c|c|c|c|c|}
\hline Rat (Case) & 12-14 days & 40 & 60 & 80 & 120 \\
\hline 1 & $\begin{array}{l}\text { Claw flexion of the } \\
\text { toes (bilateral). }\end{array}$ & $\begin{array}{l}\text { Flexion of the thigh and an- } \\
\text { kle, standing on } 4 \text { feet (origi- } \\
\text { nal position). No strength. }\end{array}$ & $\begin{array}{l}\text { Movement of the thigh, ankle and } \\
\text { hip, walks on } 4 \text { feet. Grips the mesh } \\
\text { with } 4 \text { feet. Recovery of strength. } \\
\end{array}$ & $\begin{array}{l}\text { Died at } 80 \text { days. Extraction of the spinal } \\
\text { cord before death. }\end{array}$ & \\
\hline 2 & $\begin{array}{l}\text { Claw flexion of the } \\
\text { toes (bilateral). }\end{array}$ & $\begin{array}{l}\text { Flexion of the thigh and an- } \\
\text { kle, standing on } 4 \text { feet (origi- } \\
\text { nal position). No strength. }\end{array}$ & $\begin{array}{l}\text { Movement of the thigh, ankle and } \\
\text { hip. Grips the mesh with } 4 \text { feet. Re- } \\
\text { covery of strength. }\end{array}$ & $\begin{array}{l}\text { Walks on } 4 \text { feet, speed and coordination of } \\
\text { the movements of the hind feet recovered. }\end{array}$ & $\begin{array}{l}\text { Drags the body with the hind } \\
\text { feet (coordinated and rapid flex- } \\
\text { ion and extension of the thigh, } \\
\text { knee and the hip). }\end{array}$ \\
\hline 3 & $\begin{array}{l}\text { Bilateral claw flex- } \\
\text { ion of the right } \\
\text { muscle. }\end{array}$ & $\begin{array}{l}\text { Bilateral flexion of the thigh } \\
\text { and ankle, standing on } 4 \\
\text { feet (original position). No } \\
\text { strength. }\end{array}$ & $\begin{array}{l}\text { Bilateral movement of the thigh, } \\
\text { ankle and hip, walks on } 4 \text { feet. Grips } \\
\text { the mesh with } 4 \text { feet. Recovery of } \\
\text { strength. }\end{array}$ & $\begin{array}{l}\text { Walks on } 4 \text { feet. Recovery of speed and } \\
\text { coordination of the movements of the hind } \\
\text { feet. }\end{array}$ & $\begin{array}{l}\text { Drags the body with the hind } \\
\text { feet (coordinated and rapid flex- } \\
\text { ion and extension of the thigh, } \\
\text { knee and hip). }\end{array}$ \\
\hline 4 & $\begin{array}{l}\text { Bilateral claw flex- } \\
\text { ion of the toes. }\end{array}$ & $\begin{array}{l}\text { Flexion of the left thigh and } \\
\text { ankle, standing on } 3 \text { feet, the } \\
\text { right foot remains extended } \\
\text { behind. }\end{array}$ & $\begin{array}{l}\text { Movement of the left thigh, ankle and } \\
\text { hip (Flexion and extension), walks on } \\
3 \text { feet. Grips the mesh with } 3 \text { feet. }\end{array}$ & $\begin{array}{l}\text { Bilateral movement of the thigh, ankle and } \\
\text { hip (Flexion and extension), walking on } 4 \\
\text { fours. Grips the mesh with } 4 \text { feet. Recov- } \\
\text { ery of strength. }\end{array}$ & $\begin{array}{l}\text { Walks on } 3 \text { feet with greater } \\
\text { speed and coordinated move- } \\
\text { ments. Increased strength of } \\
\text { the right hind foot. }\end{array}$ \\
\hline 5 & $\begin{array}{l}\text { Bilateral claw flex- } \\
\text { ion of the toes. }\end{array}$ & $\begin{array}{l}\text { Bilateral flexion of the thigh } \\
\text { and ankle. Standing on } 4 \\
\text { feet (original position). No } \\
\text { strength. }\end{array}$ & $\begin{array}{l}\text { Bilateral movement of the thigh, an- } \\
\text { kle and hip (Flexion and extension), } \\
\text { walks on } 4 \text { feet. Grips the mesh with } \\
4 \text { feet. }\end{array}$ & $\begin{array}{l}\text { Bilateral movement of the thigh, ankle and } \\
\text { hip (Flexion and extension), walking on } 4 \\
\text { feet. Recovery of strength. }\end{array}$ & \\
\hline
\end{tabular}




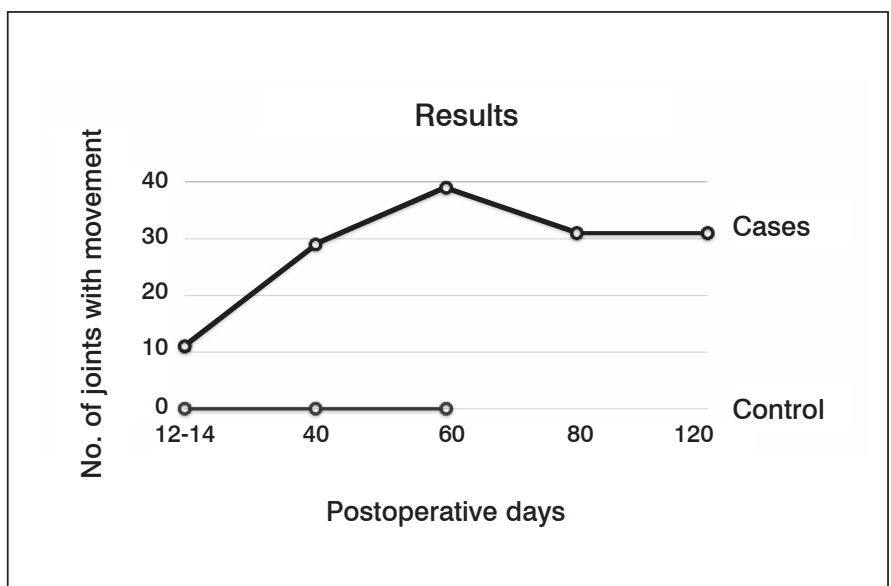

Figure 2. Olfactory bulb transplantation in acute spinal cord injury: An experimental study.

During the surgical procedure to remove the spinal cord, the scar tissue was minimal, facilitating the procedure and enabling the spinal cord to be more easily dissected. Once the spinal cord was exposed, its continuity through the transplantation site was observed, without identifying the olfactory bulb or the gap between the extremities of the sectioned area, resembling an intact spinal cord.

Histological studies showed the presence of neural tissue at the site of the lesion, with few glioses in the case samples, which were stained with hematoxylin and eosin.

Immunohistochemically, in the samples dyed with glial fibrillary acidic protein, evidence of continuity of the axonal tissue was observed, indicating regeneration of the spinal cord in the case samples. (Figures 3 and 4)

No control sample showed findings of axonal regeneration, but abundant glioses were found.

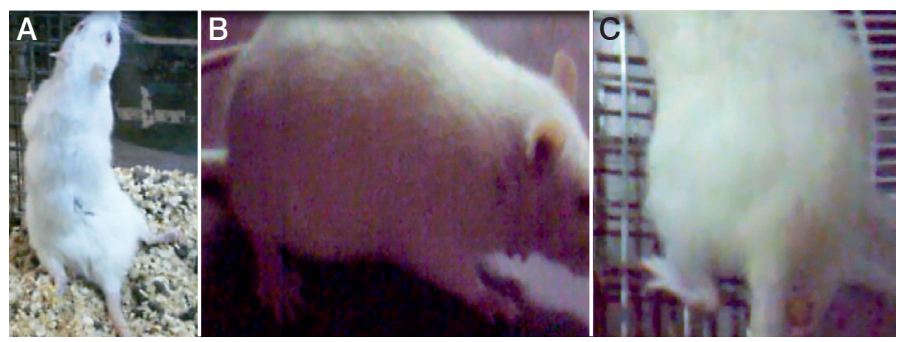

Figure 3. A) Case rat first week postoperative, paraplegia of the hind feet is observed. B) Case rat 60 days postoperative, there is recovery of mobility and strength of the hind feet. C) 120 days postoperative, recovery of fine movements in the toes of the hind feet is observed.

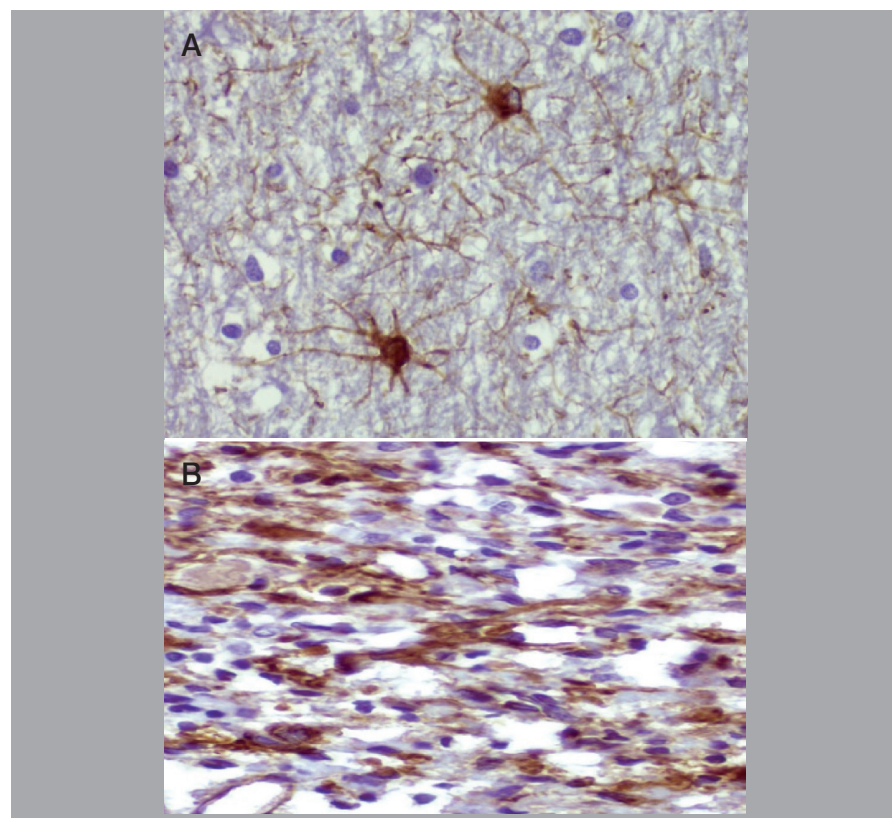

Figure 4. A) Sample of brain with GFAP, neurons and axons are shown in coffee color. B) Area of spinal cord section of case rat; continuity of the neural tissue and axional connection is observed.

\section{CONCLUSION}

Intraspinal transplantation of the olfactory ensheathing cells improves locomotor function and stimulates axonal regeneration in rats with acute spinal cord injuries, suggesting its possible efficacy in humans. However, spinal cord injury in laboratory animals cannot accurately model the inherent heterogeneity of the neurological damage seen in patients, nor is it possible to objectively assess all aspects of spinal cord function.

These findings prompt us to continue to conduct research on this subject, as they are important for the development of future treatments for spinal cord injured patients, which so far remains an incapacitating condition for life.

\section{ACKNOWLEDGMENTS}

Dr. Valeria Garcia, medical intern of the ISSSTE for her support in the care and handling of animals during the experimentation study.

All authors declare no potential conflict of interest concerning this article.

\section{REFERENCES}

1. Radtke C, Wewetzer K, Reimers K, Vogt PM. Transplantation of olfactory ensheathing cells as adjunct cell therapy for peripheral nerve injury. Cell Transplant. 2011:20(2):145-52

2. Ramón-Cueto A, Muñoz-Quiles C. Clinical application of adult olfactory bulb ensheathing glia for nervous system repair. Exp Neurol. 2011;229(1):181-94.

3. Blumenthal J, Cohen-Matsliah SI, Levenberg S. Olfactory bulb-derived cells seeded on 3D scaffolds exhibit neurotrophic factor expression and pro-angiogenic properties. Tissue Eng Part A. 2013;19(19-20):2284-91.

4. Granger N, Blamires $H$, Franklin RJ, Jeffery ND. Autologous olfactory mucosal cell transplants in clinical spinal cord injury: a randomized double-blinded trial in a canine translational model. Brain. 2012;135(11):3227-37.

5. Wu J, Sun T, Ye C, Yao J, Zhu B, He H. Clinical observation of fetal olfactory ensheathing glia transplantation (OEGT) in patients with complete chronic spinal cord injury. Cell Transplant. 2012;21(Suppl 1):33-7.
6. Mackay-Sim A, St John JA. Olfactory ensheathing cells from the nose: clinical application in human spinal cord injuries. Exp Neurol. 2011;229(1):174-80.

7. Tetzlaff W, Okon EB, Karimi-Abdolrezaee S, Hill CE, Sparling JS, Plemel JR, et al. A sys tematic review of cellular transplantation therapies for spinal cord injury. J Neurotrauma. 2011;28(8):1611-82

8. Reier PJ. Cellular transplantation strategies for spinal cord injury and translational neurobiology. NeuroRx. 2004;1(4):424-51.

9. Franssen $\mathrm{EH}$, de Bree FM, Verhaagen J. Olfactory ensheathing glia: their contribution to primary olfactory nervous system regeneration and their regenerative potential following transplantation into the injured spinal cord. Brain Res Rev. 2007;56(1):236-58.

10. Lu J, Féron F, Mackay-Sim A, Waite PM. Olfactory ensheathing cells promote locomotor recovery after delayed transplantation into transected spinal cord. Brain. 2002;125(Pt 1):14-21 